\title{
Pengaruh Suhu dan Waktu Pengeringan terhadap Karakteristik Kimia serta Sensori Teh Daun Bambu Tabah (Gigantochloa nigrociliata BUSE-KURZ).
}

\section{Effect of Temperature and Drying Time on Chemical Characteristics and Sensory of Tabah Bamboo Leaf Tea (Gigantochloa nigrociliata BUSE-KURZ)}

\author{
I Kadek Wirawan, Pande Ketut Diah Kencana*, I Made Supartha Utama \\ Program Studi Teknik Pertanian, Fakultas Teknologi Pertanian, Universitas Udayana, Badung, Bali Indonesia \\ *E-mail: supartha_utama@unud.ac.id
}

\begin{abstract}
Abstrak
Penelitian ini bertujuan untuk mengetahui Pengaruh Suhu dan Waktu Pengeringan terhadap Karakteristik Kimia serta Sensori Teh Daun Bambu Tabah. Penelitian ini dirancang menggunakan Rancangan Acak Lengkap (RAL) dengan dua faktor, yaitu faktor suhu pengeringan $\left(50^{\circ} \mathrm{C}, 60^{\circ}\right.$ C) dan faktor waktu pengeringan (1 jam, 2 jam, 3 jam). Perlakuan diulang tiga kali sehingga mendapatkan 18 unit percobaan. Parameter yang diamati adalah kadar air, $\mathrm{pH}$, total asam, total fenol, dan organoleptik. Hasil penelitian menunjukkan bahwa interaksi suhu dan waktu pengeringan teh daun bambu tabah memiliki pengaruh berbeda nyata terhadap kadar air, $\mathrm{pH}$, total asam, total fenol, warna, dan penerimaan keseluruhan, tetapi tidak memiliki pengaruh yang berbeda nyata terhadap aroma dan rasa. Perlakuan terbaik kadar air 6,88 \%, pH 6,6, total asam $0,73 \%$, total fenol $84,01 \mathrm{mg} / 100 \mathrm{~g}$, warna 4,33 , aroma 4,47 , rasa 4,27 dan penerimaan keseluruhan 4,47 .
\end{abstract}

Kata kunci: daun bambu Tabah, teh herbal, suhu pengeringan, waktu pengeringan, total fenol.

\begin{abstract}
This study aimd to determine the effect of temperature and drying time on the chemical and sensory characteristics of Tabah bamboo leaf tea. This study was designed using a Completely Randomized Design (CRD) with two factors, namely the drying temperature factor $\left(50^{\circ} \mathrm{C}\right.$ and $60^{\circ} \mathrm{C}$ ) and the drying time factor ( 1 hour, 2 hours, and 3 hours). The treatment was repeated three times to obtain 18 experimental units. The parameters observed were water content, $\mathrm{pH}$, total acid, total phenol, color, aroma, taste, and overall acceptance tested organoleptically. The results showed that the interaction of temperature and duration of drying of Tabah bamboo tea leaves had a significantly different effect on water content, $\mathrm{pH}$, total acid, total phenol, color, overall reception, but did not have a significantly different effect on aroma and taste. The best treatment was water content $6.881 \%$, pH 6.6 , total acid $0.73 \%$, total phenol $84.01 \mathrm{mg} / 100 \mathrm{~g}$, color 4.33 , aroma 4.47, taste 4.27 and overall acceptance 4.47 .
\end{abstract}

Keywords: Tabah bamboo leaves, herbal tea, drying temperature, drying time, total phenol.

\section{PENDAHULUAN}

Bambu adalah tanaman jenis rumput-rumputan dengan rongga dan ruas dibatangnya. Bambu merupakan tanaman serbaguna dan sering dimanfaatkan dalam kehidupan sehari-hari oleh masyarakat Indonesia. Menurut Morisco (2006) bambu merupakan tanaman yang cepat tumbuh dan dapat dipanen pada umur 3-5 tahun tanpa menanam kembali.

Di Indonesia terdapat 161 jenis bambu yang tumbuh dan \pm 40 jenis tumbuh di Bali. Salah satunya adalah bambu tabah (Gigantochloa nigrociliata BUSEKURZ) yang tumbuh baik di daerah Pupuan, Kabupaten Tabanan, Provinsi Bali. Menurut Kencana et al., (2012) Pemanfaatan bambu tabah baru pengambilan rebungnya saja untuk dikomersialkan serta dikonsumsi sehari-hari. Namun pemanfaatan daun bambu tabah belum dilakukan, sehingga peneliti memanfaatkan daun bambu tabah sebagai produk kering seperti teh herbal.

Menurut Hambali et al., (2005) menyebutkan teh herbal bisanya disajikan dalam bentuk kering seperti penyajian dari tanaman Camellia sinensis. Teh adalah minuman yang mengandung tanin dan polifenol, dibuat dengan cara menyeduh daun, pucuk daun, atau tangkai daun yang dikeringkan dari tanaman Camellia sinensis dengan air panas (Sembiring, 2009). Sedangkan teh herbal merupakan salah satu produk minuman yang bukan dari tanaman Camellia 
sinensis melainkan berasal dari tanaman herbal sehingga memiliki khasiat dalam membantu pengobatan suatu penyakit atau sebagai penyegar. Teh herbal umumnya campuran dari beberapa bahan yang berasal daun kering, biji, kayu, buah, bunga, dan tanaman lain yang memiliki manfaat (Ravikumar, 2014).

Menurur Widiarso, B. P. et al., (2019) penelitian menunjukkan Senyawa kimia daun bambu mengandung banyak zat aktif, yakni flavonoid, polisakarida, klorofil, asam amino, dan mikroelemen. Sehingga baik untuk menurunkan lemak darah dan kolesterol, dipercaya bisa menurunkan oksidasi atau radikal bebas, sebagai bahan anti penuaan, serta mampu menjaga stamina dan mencegah penyakit kardiovaskular. Didukung dengan pernyataan Zhang et al., (2005) menyatakan bahwa pada daun bambu mengandung komponen bioaktif cukup tinggi, antara lain mengandung flavonoid, lakton, dan asam fenolat yaitu senyawa-senyawa yang berperan sebagai antioksidan dan anti mikrobial, sehingga ketiga senyawa ini berguna sebagai menunjang bagi kesehatan tubuh.

Pembuatan teh herbal daun bambu tabah menggunakan kombinasi antara perlakuan suhu dan waktu pengeringan yang bertujuan untuk mengetahui karakteristik kimia dan sensori produk teh daun bambu tabah. Serta untuk mengetahui kombinasi yang terbaik untuk karakteristik kimia dan sensori produk teh daun bambu tabah.

Pengeringan merupakan proses pengeluaran air dari dalam bahan, dan proses menggunakan panas untuk menghasilkan produk kering. Metode pengeringan yang digunakan pada penelitian ini yaitu pengeringan secara non konvensional (pengeringan dengan oven). Menurut Hartuti, (1997) menyatakan pengeringan oven memiliki keunggulan yaitu suhu yang digunakan mudah untuk diatur. Tujuan dari proses pengeringan ini yaitu untuk menurunkan kadar air sehingga bahan tersebut tidak mudah ditumbuhi kapang dan bakteri, menghilangkan aktivitas enzim yang bisa merugikan kandungan zat aktif dalam bahan, serta memudahkan dalam hal pengelolaan proses selanjutnya (Gunawan dan Mulyani, 2004).

\section{METODE}

\section{Waktu dan Tempat Penelitian}

Penelitian dilaksanakan pada bulan April sampai dengan bulan Juni 2019. Penelitian dilakukan di Laboratorium Pascapanen, Laboratorium Pengelolaan Sumber Daya Alam, Laboratorium Analisis Pangan, Laboratorium Biokimia dan Nutrisi Fakultas Teknologi Pertanian, Universitas Udayana.

\section{Bahan dan Alat Penelitian}

Bahan utama yang digunakan dalam penelitian ini adalah daun bambu tabah. Daun bambu yang digunakan yaitu dari pucuk hingga daun ketiga pada setiap ranting bambu tabah. Sedangkan bahan kimia yang digunakan untuk analisis yaitu aquades, $\mathrm{NaOH}$ $0.1 \mathrm{~N}$, Methanol (pa) $85 \%$, Natrium Bikarbonat $\left(\mathrm{Na}_{2} \mathrm{CO}_{3}\right)$, Folin-Ciocalteu, Larutan PP, Asam Galat. Alat yang digunakan untuk proses pengeringan adalah oven, nampan, gunting, keranjang. Alat dan instrumen yang digunakan untuk pembuatan teh dan uji sifat kimia adalah blender, ayakan 40 mesh, timbangan analitik, pinset, spatula, gelas backer, labu ukur $100 \mathrm{ml}$ dan $5 \mathrm{ml}$, pipet, bola hisap, gelas ukur, pipet volumetrik $1000 \mathrm{mc}$, vortex, tabung sentripugle, kuvet, spektrofotometer, $\mathrm{pH}$ meter, kantong celup.

\section{Rancangan Penelitian}

Rancangan percobaan yang digunakan dalam penelitian ini adalah Rancangan Acak Lengkap (RAL) dengan 2 faktor sebagai perlakuan. Faktor I yaitu suhu pengeringan ( $\mathrm{T}$ ) dengan 2 perlakuan, antara lain $\mathrm{T}_{1}=50^{\circ} \mathrm{C}, \mathrm{T}_{2}=60^{\circ} \mathrm{C}$, dan faktor II yaitu waktu pengeringan $(\mathrm{t})$ dengan 3 perlakuan, antara lain $\mathrm{t}_{1}=1 \mathrm{jam}, \mathrm{t}_{2}=2 \mathrm{jam}$, dan $\mathrm{t}_{3}=3 \mathrm{jam}$. Seluruh perlakuan diulang sebanyak 3 kali ulangan sehingga didapatkan 18 data pengamatan. Data yang diperoleh dianalisis dengan sidik ragam, apabila terdapat pengaruh perlakuan yang signifikan $(\mathrm{P}<0.05)$ maka dilanjutkan dengan uji Duncan atau BNT terhadap rata-rata perlakuan.

\section{Pelaksanaan Penelitian \\ Persiapan Bahan Baku Daun Bambu Tabah}

Bahan baku digunakan pada penelitian ini yaitu daun bambu tabah yang diperoleh dari Desa padangan, Kecamatan Pupuan, Kabupaten Tabanan. Daun bambu yang siap dipanen yaitu bambu sudah berumur \pm 2 tahun, Daun bambu yang digunakan yaitu dari pucuk hingga daun ketiga pada setiap ranting bambu tabah. Pemetikan daun bambu tabah dilakukan pada pagi hari (07.00 - 10.00 WITA), daun yang sudah dipetik dilakukan proses penimbangan sebanyak $3 \mathrm{~kg}$, selanjutnya dikemas dan dimasukkan ke dalam cold storage yang bertujuan untuk menjaga kesegaran daun bambu. Daun bambu yang sudah dikemas kemudian dimasukkan ke dalam styrofoam box dan diangkut menuju Laboratrium Teknik Pascapanen, Program Studi Teknik Pertanian, Fakultas Teknologi Pertanian, Universitas Udayana dan dimasukkan ke dalam softcase.

\section{Proses Pembuatan Teh Daun Bambu Tabah}

Proses pembuatan Teh Daun Bambu Tabah diawali dengan sortasi bahan baku dengan cara memilih atau memisahkan daun bambu (pucuk dan 3 daun di bawahnya) yang baik dengan daun bambu yang rusak atau cacat, dilanjutkan dengan proses pemotongan pangkal dan ujung daun bambu yang bertujuan untuk dapat mempermudah pada saat perajangan, dilanjutkan dengan proses pencucian bahan baku 
untuk membersihkan debu atau kotoran yang masih melekat pada bahan, dilanjutkan proses penirisan menggunakan keranjang selama 30 menit sehingga sisa air yang digunakan pada proses pencucian berkurang. Proses perajangan (pengecilan ukuran) daun bambu tabah dengan menggunakan gunting atau pisau dengan ketebalan $0,5-1 \mathrm{~cm}$.

Tahap selanjutnya yaitu proses pengeringan yang bertujuan untuk mengurangi kadar air pada daun bambu tabah hingga batas tertentu yang menyebabkan teh manjadi lebih awet. Pengeringan dilakukan menggunakan oven dengan suhu pengeringan $50^{\circ} \mathrm{C}, 60^{\circ} \mathrm{C}$, dengan waktu pengeringan yaitu 1 jam, 2 jam, dan 3 jam. Proses penghalusan bahan dengan menggunakan blender jenis philip dengan tujuan untuk mempermudah dalam proses analisis kimia pada bahan, bahan yang sudah diblender kemudian diayak menggunakan pengayak berukuran 40 mesh sehingga memisahkan antara bahan layak lolos dan tidak layak lolos, kemudian dilakukan proses pengemasan yang bertujuan untuk memperpanjang daya simpan bahan.

Tahap selanjutnya menganalisis kandungan kimia pada teh daun bambu tabah yaitu kadar air, $\mathrm{pH}$, total asam, dan total fenol. Sedangkan pengujian organoleptik (warna, aroma, dan rasa) secara sensori dilakukan setelah penyeduhan teh daun bambu tabah. Proses penyeduhan dilakukan dengan mengambil daun bambu tabah yang sudah dimasukkan ke dalam kantong teh yang berisi $3 \mathrm{~g}$ dan ditambahkan air panas sebanyak $200 \mathrm{ml}$ selama 5 menit, kemudian dilakukan uji organoleptik dari segi warna, aroma, dan rasa pada teh daun bambu.

\section{Parameter Pengamatan}

Pada penelitian ini dilakukan pengamatan yang meliputi antara lain kadar air (Sudarmadji et al., 1997), pH (AOAC, 1995), total asam (Wahyudi, 2006), total fenol (Javanmardi et al., 2003) dan uji organoleptik berdasarkan (SNI: 01- 394-2016).

\section{HASIL DAN PEMBAHASAN}

\section{Kadar Air}

Hasil dari analisis sidik ragam menunjukkan bahwa interaksi suhu pengeringan dan waktu pengeringan berpengaruh nyata terhadap kadar air teh daun bambu tabah $(\mathrm{P}<0,05)$. Adapun hasil kadar air yang ditampilkan pada Gambar 1. Hasil analisis sidik ragam teh daun bambu tabah menunjukan nilai $\mathrm{F}$ hitung lebih besar dari nilai $\mathrm{F}$ tabel 5\%, menunjukkan adanya pengaruh nyata dari perlakuan suhu dan waktu pengeringan terhadap kadar air. Selanjutnya dilakukan uji BNT 5\%. Hasil uji BNT 5\% menunjukan bahwa perlakuan $\mathrm{T}_{1} \mathrm{t}_{1}\left(50^{\circ} \mathrm{C}, 1\right.$ jam $)$ berbeda nyata dengan perlakuan $\mathrm{T}_{2} \mathrm{t}_{1}\left(60^{\circ} \mathrm{C}, 1\right.$ jam $)$, $\mathrm{T}_{1} \mathrm{t}_{2}\left(50^{\circ} \mathrm{C}, 2\right.$ jam $)$ berbeda nyata dengan perlakuan
$\mathrm{T}_{2} \mathrm{t}_{2}\left(60^{\circ} \mathrm{C}, 2 \mathrm{jam}\right)$, dan $\mathrm{T}_{1} \mathrm{t}_{3}\left(50^{\circ} \mathrm{C}, 3 \mathrm{jam}\right)$ berbeda nyata dengan perlakuan $\mathrm{T}_{2} \mathrm{t}_{3}\left(60^{\circ} \mathrm{C}, 3 \mathrm{jam}\right)$.

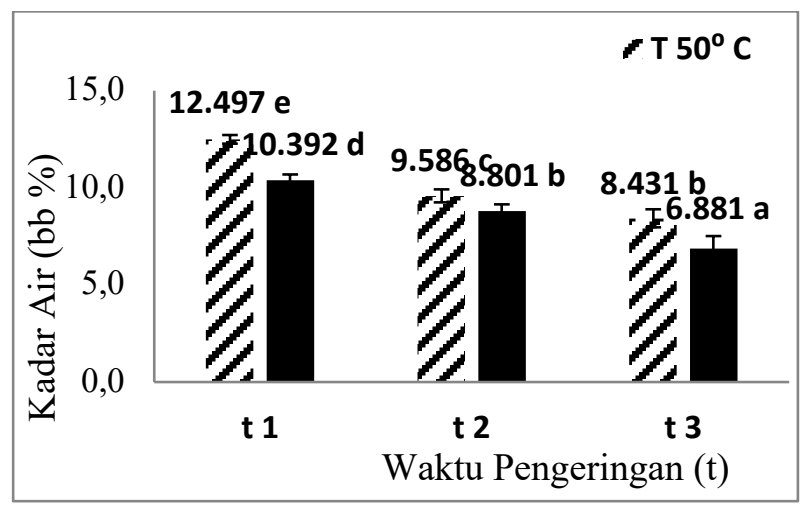

Gambar 1. Hubungan antara Suhu dan Waktu pengeringan terhadap kadar air teh daun bambu tabah. Keterangan: 1. Huruf yang berbeda dibelakang angka pada kolom menunjukan adanya perbedaan yang segnifikan berdasarkan uji BNT $(\mathrm{P}<0.05)$.

Berdasarkan hasil penelitian menunjukkan bahwa nilai kadar air (bb \%) yang didapatkan dari perlakuan suhu dan waktu pengeringan teh daun bambu tabah memilik rata-rata antara $12,497-6,881 \%$. Nilai kadar air tertinggi terdapat pada perlakuan $\mathrm{T}_{1} \mathrm{t}_{1}\left(50^{\circ}\right.$ C, 1 jam) yaitu $12,497 \%$. Sedangkan nilai kadar air terendah terdapat pada perlakuan $\mathrm{T}_{2} \mathrm{t}_{3}\left(60^{\circ} \mathrm{C}, 3 \mathrm{jam}\right)$ yaitu 6,881. Hal ini diduga selama proses pengeringan terjadi penguapan air dari bahan ke udara yang dapat menurunkan kadar air pada teh daun bambu tabah. Menurut Winarno (1997) semakin lama proses pengeringan yang dilakukan maka panas yang diterima oleh bahan akan lebih banyak, sehingga jumlah air yang diuapkan dalam bahan pangan tersebut semakin banyak dan kadar air yang terukur menjadi rendah.

Berdasarkan standar pengujian SNI 3945-2016 kadar air teh hijau maksimal $8 \%$, sehingga kadar air pada perlakuan $\mathrm{T}_{2} \mathrm{t}_{3}\left(60^{\circ} \mathrm{C}, 3 \mathrm{jam}\right)$ sudah memenuhi standar yang ditetapkan, sedangkan perlakuan $\mathrm{T}_{1} \mathrm{t}_{1}\left(50^{\circ} \mathrm{C}, 1\right.$ jam $), \mathrm{T}_{1} \mathrm{t}_{2}\left(50^{\circ} \mathrm{C}, 2 \mathrm{jam}\right), \mathrm{T}_{1} \mathrm{t}_{3}\left(50^{\circ} \mathrm{C}, 3 \mathrm{jam}\right), \mathrm{T}_{2} \mathrm{t}_{1}\left(60^{\circ}\right.$ $\mathrm{C}, 1 \mathrm{jam})$, dan $\mathrm{T}_{2} \mathrm{t}_{2}\left(60^{\circ} \mathrm{C}, 2 \mathrm{jam}\right)$ belum memenuhi standar pengujian SNI dikarenakan kadar air yang diperoleh masih tinggi yaitu di atas $8 \%$. Hal ini diduga suhu dan waktu pengeringan yang digunakan belum mampu menguapkan air pada bahan secara maksimal. Menurut Adri, D., dan Hersoelistyorini, W. (2013) komposisi air pada bahan pangan seperti air bebas dan air terikat dapat mempengaruhi laju atau lama pengeringan bahan pangan.

\section{Nilai pH}

Hasil dari analisis sidik ragam menunjukkan bahwa interaksi suhu pengeringan dan waktu pengeringan berpengaruh nyata terhadap $\mathrm{pH}$ teh daun bambu tabah 
( $\mathrm{P}<0,05)$. Adapun hasil $\mathrm{pH}$ yang ditampilkan pada Gambar 2.

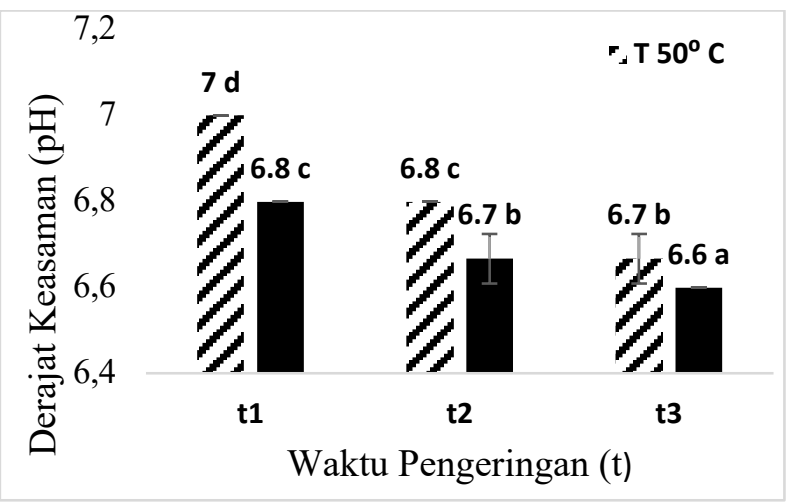

Gambar 2. Hubungan antara Suhu dan Waktu pengeringan terhadap $\mathrm{pH}$ teh daun bambu tabah. Keterangan: 2. Huruf yang berbeda dibelakang angka pada kolom menunjukan adanya perbedaan yang segnifikan berdasarkan uji BNT $(\mathrm{P}<0.05)$.

Hasil analisis sidik ragam teh daun bambu tabah menunjukan nilai $\mathrm{F}$ hitung lebih besar dari nilai $\mathrm{F}$ tabel $5 \%$, menunjukkan adanya pengaruh nyata dari perlakuan suhu dan waktu pengeringan terhadap $\mathrm{pH}$ teh daun bambu tabah. Selanjutnya perlu adanya perlakuan uji BNT 5\%. Hasil uji BNT 5\% menunjukan bahwa perlakuan $\mathrm{T}_{1} \mathrm{t}_{1}\left(50^{0} \mathrm{C}, 1 \mathrm{jam}\right)$ berbeda nyata dengan perlakuan $\mathrm{T}_{1} \mathrm{t}_{2}\left(50^{\circ} \mathrm{C}, 2 \mathrm{jam}\right)$, $\mathrm{T}_{2} \mathrm{t}_{1}\left(60^{\circ} \mathrm{C}, 1 \mathrm{jam}\right)$, berbeda nyata dengan perlakuan $\mathrm{T}_{1} \mathrm{t}_{3}\left(50^{\circ} \mathrm{C}, 3 \mathrm{jam}\right), \mathrm{T}_{2} \mathrm{t}_{2}\left(60^{\circ} \mathrm{C}, 2 \mathrm{jam}\right)$, dan berbeda nyata dengan perlakuan $\mathrm{T}_{2} \mathrm{t}_{3}\left(60^{\circ} \mathrm{C}, 3 \mathrm{jam}\right)$.

Berdasarkan hasil penelitian menunjukan bahwa nilai $\mathrm{pH}$ yang didapatkan dari perlakuan suhu dan waktu pengeringan teh daun bambu tabah memilik rata-rata antara $7-6,6$. Nilai $\mathrm{pH}$ tertinggi terdapat pada perlakuan $\mathrm{T}_{1} \mathrm{t}_{1}\left(50^{\circ} \mathrm{C}, 1\right.$ jam $)$ yaitu 7,0 .

Sedangkan nilai $\mathrm{pH}$ terendah terdapat pada perlakuan $\mathrm{T}_{2} \mathrm{t}_{3}\left(60^{\circ} \mathrm{C}, 3 \mathrm{jam}\right)$ yaitu 6,6 . Hal ini diduga terbentuknya asam pada produk yang dihasilkan oleh aktivitas enzim serta adanya kandungan pati atau gula dalam bahan. Menurut Safriani. N (2014) molekul pati cenderung menarik partikel bermuatan negatif. Penarikan ion $\mathrm{OH}^{-}$ke sekitar molekul gula akan mengakibatkan konsentrasi ion $\mathrm{H}^{+}$dalam larutan meningkat sehingga $\mathrm{pH}$ akan menurun.

\section{Kadar Total Asam}

Hasil dari analisis sidik ragam menunjukkan bahwa interaksi suhu pengeringan dan waktu pengeringan berpengaruh nyata terhadap total asam teh daun bambu tabah $(\mathrm{P}<0,05)$. Adapun hasil total asam yang ditampilkan pada Gambar 3.

Hasil analisis sidik ragam teh daun bambu tabah menunjukan nilai $\mathrm{F}$ hitung lebih besar dari nilai $\mathrm{F}$ tabel 5\%, menunjukkan adanya pengaruh nyata dari perlakuan suhu dan waktu pengeringan terhadap total asam teh daun bambu tabah. Selanjutnya dilakukan uji BNT 5\%. Hasil uji BNT 5\% menunjukan bahwa perlakuan $\mathrm{T}_{1} \mathrm{t}_{1}\left(50^{\circ} \mathrm{C}, 1 \mathrm{jam}\right)$ berbeda nyata dengan perlakuan $\mathrm{T}_{1} \mathrm{t}_{2}\left(50^{\circ} \mathrm{C}, 2 \mathrm{jam}\right), \mathrm{T}_{1} \mathrm{t}_{3}\left(50^{\circ} \mathrm{C}, 3 \mathrm{jam}\right), \mathrm{T}_{2} \mathrm{t}_{1}$ $\left(60^{\circ} \mathrm{C}, 1 \mathrm{jam}\right), \mathrm{T}_{2} \mathrm{t}_{2}\left(60^{\circ} \mathrm{C}, 2 \mathrm{jam}\right)$ berbeda nyata dengan perlakuan $\mathrm{T}_{2} \mathrm{t}_{3}\left(60^{\circ} \mathrm{C}, 3 \mathrm{jam}\right)$.

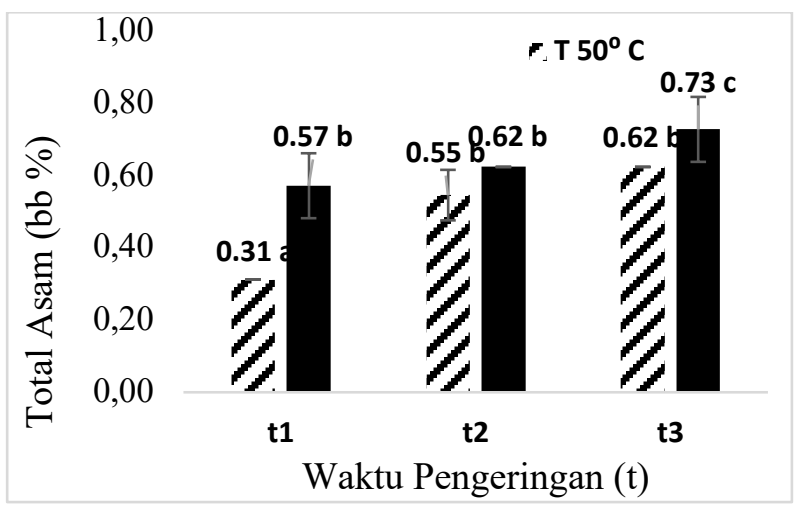

Gambar 3. Hubungan antara Suhu dan Waktu pengeringan terhadap total asam teh daun bambu tabah. Keterangan: 3 . Huruf yang berbeda dibelakang angka pada kolom menunjukan adanya perbedaan yang segnifikan berdasarkan uji $\mathrm{BNT}(\mathrm{P}<0.05)$.

Berdasarkan hasil penelitian menunjukan bahwa nilai total asam (bb \%) yang didapatkan dari perlakuan suhu dan waktu pengeringan teh daun bambu tabah memilik rata-rata antara $0,31-0,73 \%$. Nilai total asam tertinggi terdapat pada perlakuan $\mathrm{T}_{2} \mathrm{t}_{3}\left(60^{\circ} \mathrm{C}, 3\right.$ jam) yaitu $0,73 \%$. Sedangkan nilai total asam terendah terdapat pada perlakuan $\mathrm{T}_{1} \mathrm{t}_{1}\left(50^{\circ} \mathrm{C}, 1 \mathrm{jam}\right)$ yaitu $0,31 \%$. Menurut Vesania, M. B. (2016) total asam berhubungan erat dengan nilai $\mathrm{pH}$, dimana kenaikan total asam menunjuk penurunan pada nilai $\mathrm{pH}$. Pada pengukuran total asam tertitrasi komponen asam yang terdisosiasi ikut terukur, sedangkan pada pengukuran $\mathrm{pH}$ hanya komponen asam saja yang terukur (Sukandar, D. 2014). Total asam tertitrasi merupakan presentase asam dalam bahan yang ditentukan secara tertitrasi dengan basa standar. Salah satu faktor yang berhubungan dengan kestabilan mutu produk pangan adalah total asam. Keawetan bahan pangan untuk disimpan lebih lama bergantung pada total asam yang ada dalam bahan pangan tersebut (Diantoro, A. 2015).

\section{Kadar Total Fenol}

Hasil dari analisis sidik ragam menunjukkan bahwa interaksi suhu pengeringan dan waktu pengeringan berpengaruh nyata terhadap kandungan total fenol teh daun bambu tabah $(\mathrm{P}<0,05)$. Adapun hasil total fenol yang ditampilkan pada Gambar 4.

Hasil analisis sidik ragam teh daun bambu tabah menunjukan nilai $\mathrm{F}$ hitung lebih besar dari nilai $\mathrm{F}$ tabel 5\%, menunjukkan adanya pengaruh nyata dari 
perlakuan suhu dan waktu pengeringan terhadap total fenol teh daun bambu tabah. Selanjutnya perlu adanya perlakuan uji BNT 5\%. Hasil uji BNT 5\% menunjukan bahwa perlakuan $\mathrm{T}_{1} \mathrm{t}_{1}\left(50^{\circ} \mathrm{C}, 1\right.$ jam $)$ berbeda nyata dengan perlakuan $\mathrm{T}_{1} \mathrm{t}_{2}\left(50^{\circ} \mathrm{C}, 2 \mathrm{jam}\right)$, dan berbeda nyata dengan perlakuan $\mathrm{T}_{1} \mathrm{t}_{3}\left(50^{\circ} \mathrm{C}, 3\right.$ jam $), \mathrm{T}_{2} \mathrm{t}_{1}\left(60^{\circ} \mathrm{C}, 1 \mathrm{jam}\right), \mathrm{T}_{2} \mathrm{t}_{2}\left(60^{\circ} \mathrm{C}, 2 \mathrm{jam}\right), \mathrm{T}_{2} \mathrm{t}_{3}\left(60^{\circ}\right.$ C, 3 jam).

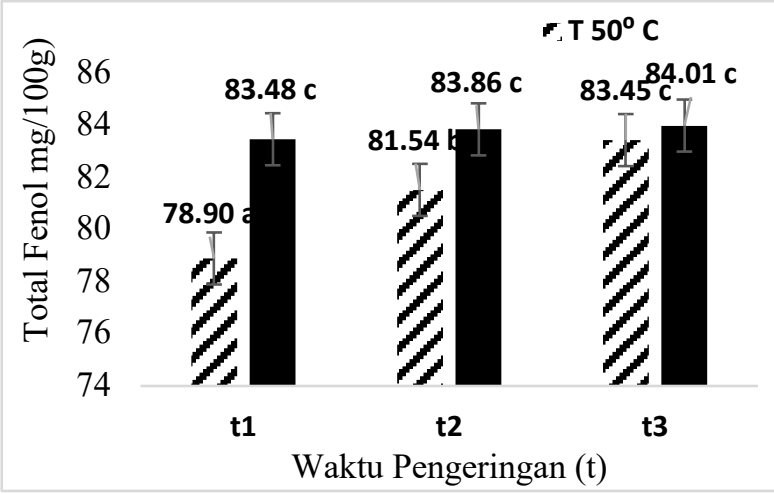

Gambar 4. Hubungan antara Suhu dan Waktu pengeringan terhadap total fenol teh daun bambu tabah. Keterangan: 4. Huruf yang berbeda dibelakang angka pada kolom menunjukan adanya perbedaan yang segnifikan berdasarkan uji BNT $(\mathrm{P}<0.05)$.

Berdasarkan hasil penelitian menunjukan bahwa nilai fenol (mg/100g ) yang didapatkan dari perlakuan suhu dan waktu pengeringan teh daun bambu tabah memilik rata-rata antara 78,90-84,01 mg/100g. Nilai total fenol tertinggi terdapat pada perlakuan $\mathrm{T}_{2} \mathrm{t}_{3}\left(60^{\circ}\right.$ C, 3 jam) yaitu $84,01 \mathrm{mg} / 100 \mathrm{~g}$. Sedangkan nilai total fenol terendah terdapat pada perlakuan $\mathrm{T}_{1} \mathrm{t}_{1}\left(50^{\circ} \mathrm{C}, 1\right.$ jam) yaitu 78,90 mg/100g. Semakin tinggi suhu dan waktu pengeringan yang digunakan maka semakin tinggi kandungan total fenol pada bahan teh daun bambu tabah. Hal ini diduga senyawa-senyawa antioksidan yang berupa asam fenolik tersebut tahan terhadap panas yang digunakan. Menurut Rofiah (2015) asam fenolik tersebut bisa aktif pada suhu $50^{\circ} \mathrm{C}, 60^{\circ} \mathrm{C}$, dan $70^{\circ} \mathrm{C}$ dengan waktu 100 menit, 160 menit, dan 180 menit. Sehingga jika pengeringan dengan suhu $60^{\circ} \mathrm{C}$ dengan lama waktu 3 jam merupakan suhu yang optimal untuk mengaktifkan senyawa fenol tersebut, namun suhu pengeringan yang terlalu tinggi yaitu pada suhu $100^{\circ} \mathrm{C}$ dapat menyebabkan penurunan kandungan fenol pada bahan. Hal ini terjadi karena panas yang terlalu tinggi dapat menyebabkan terjadinya kerusakan terhadap komponen penyusun dinding sel daun yaitu karbohidrat (termasuk serat selulosa) dan protein sebagai komponen tidak terlarut. Kerusakan ini dapat memudahkan keluarnya senyawa polifenol dari daun, hal ini dikarenakan polifenol merupakan senyawa yang memiliki berat molekul rendah, sehingga mudah untuk terinfusi ke dalam pelarut (Chu dan Juneja, 1997).

\section{Uji Sensori (Uji Skorsing) \\ Warna air seduhan}

Hasil dari analisis sidik ragam menunjukkan bahwa interaksi suhu pengeringan dan waktu pengeringan berpengaruh nyata terhadap warna air seduhan teh daun bambu tabah $(\mathrm{P}<0,05)$. Adapun hasil warna yang ditampilkan pada Gambar 5.

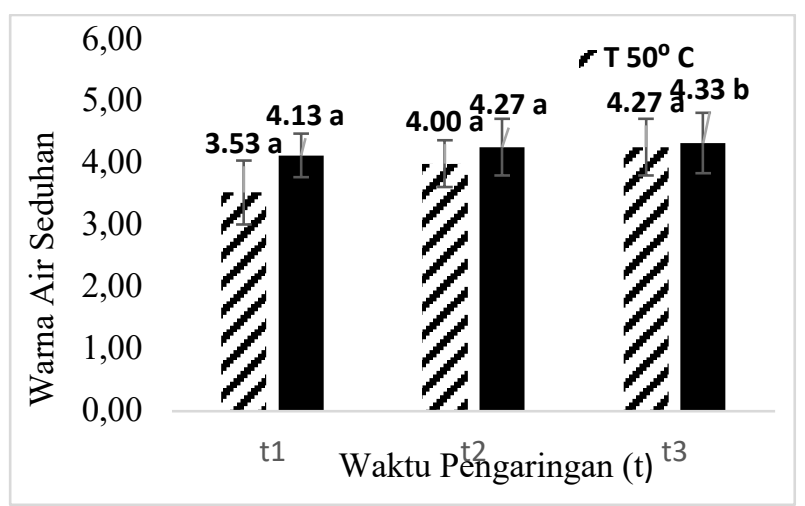

Gambar 5. Hubungan antara Suhu dan Waktu pengeringan terhadap warna seduhan teh daun bambu tabah. Keterangan: 5. Huruf yang berbedaan dibelakang angka pada kolom menunjukan adanya perbedaan yang segnifikan berdasarkan uji BNT $(\mathrm{P}<0.05)$.

Berdasarkan hasil pengujian organoleptik, tingkat kesukaan panelis terhadap warna teh daun bambu tabah yang memiliki nilai tertinggi pada perlakuan $\mathrm{T}_{2} \mathrm{t}_{3}\left(60^{\circ} \mathrm{C}, 3\right.$ jam) dengan rerata 4,33 (kuning kehijauan cerah), sedangkan warna teh daun bambu tabah yang memiliki nilai terendah adalah perlakuan $\mathrm{T}_{1} \mathrm{t}_{1}\left(50^{\circ} \mathrm{C}, 1 \mathrm{jam}\right)$ dengan rerata 3,53 (kuning kehijauan cerah).

Hasil analisis sidik ragam teh daun bambu tabah menunjukan nilai $\mathrm{F}$ hitung lebih besar dari nilai $\mathrm{F}$ tabel 5\%, menunjukkan adanya pengaruh nyata dari perlakuan suhu dan waktu pengeringan terhadap warna teh daun bambu tabah. Selanjutnya perlu adanya perlakuan uji BNT 5\%. Hasil uji BNT 5\% menunjukan bahwa perlakuan $\mathrm{T}_{1} \mathrm{t}_{1}\left(50^{\circ} \mathrm{C}, 1 \mathrm{jam}\right), \mathrm{T}_{1} \mathrm{t}_{2}$ $\left(50^{\circ} \mathrm{C}, 2 \mathrm{jam}\right), \mathrm{T}_{1} \mathrm{t}_{3}\left(50^{\circ} \mathrm{C}, 3 \mathrm{jam}\right), \mathrm{T}_{2} \mathrm{t}_{1}\left(60^{\circ} \mathrm{C}, 1 \mathrm{jam}\right)$, dan $\mathrm{T}_{2} \mathrm{t}_{2}\left(60^{\circ} \mathrm{C}, 2 \mathrm{jam}\right)$, berbeda nyata dengan perlakuan $\mathrm{T}_{2} \mathrm{t}_{3}\left(60^{\circ} \mathrm{C}, 3 \mathrm{jam}\right)$. Semakin tinggi suhu dan waktu pengeringan digunakan maka semakin meninggkat warna teh daun bambu tabah atau warna air seduhan menjadi kuning kehijauan cerah. Hal ini diduga dipengaruhi oleh refleksi dari pigmen klorofil dan karoten yang teroksidasi larut di dalal air, serta pigmen fenol yang terkandung dalam teh daun bambu tabah.

Menurut Winarno (2008) menyatakan bahwa klorofil memiliki dua gugus yang saling bertolak belakang, yaitu gugus methyl ester dan phytil ester. Adanya gugus methyl ester menyebabkan klorfil bersifat larut 
dalam pelarut organik (non polar), sedangkan adanya gugus phytil ester menyebabkan klorofil dapat larut dalam air (polar). Panas yang tinggi menyebabkan protein yang terikat dalam lipoprotein akan mengalami denaturasi. Hal ini menyebabkan klorofil terbuka terhadap reaksi kimia dari luar, khususnya gugusan phytil ester ini akan terlepas sehingga menyebabkan molekul klorofil larut dalam air (polar).

\section{Aroma air seduhan}

Hasil dari analisis sidik ragam menunjukkan bahwa interaksi perlakuan suhu pengeringan dan lama waktu pengeringan tidak memberikan pengaruh yang berbeda nyata terhadap organoleptik aroma teh daun bambu tabah $(\mathrm{P}>0,05)$. Hasil pengujian organoleptik terhadap aroma dapat dilihat pada Gambar 6 .

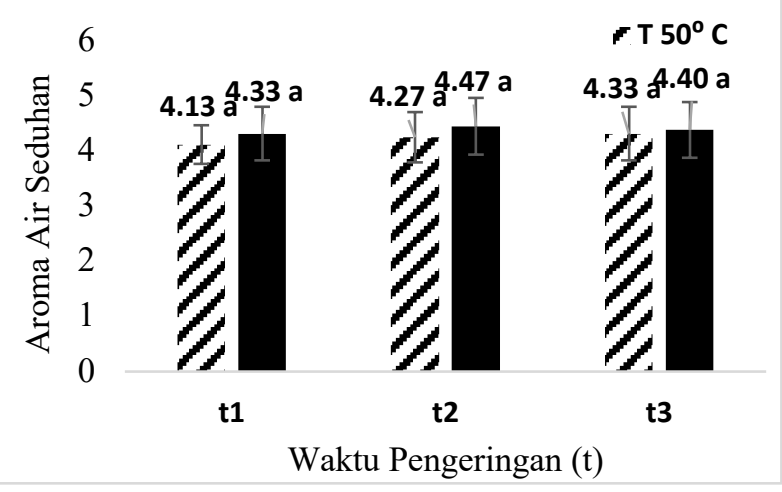

Gambar 6. Hubungan antara Suhu dan Waktu pengeringan terhadap aroma teh daun bambu tabah. Keterangan: 6. Interaksi dari perlakuan suhu dan waktu pengeringan menunjukkan tidak adanya interaksi $(\mathrm{P}>0,05)$

Berdasarkan hasil pengujian organoleptik, tingkat kesukaan panelis terhadap aroma teh daun bambu tabah yang memiliki skor tertinggi pada perlakuan $\mathrm{T}_{2} \mathrm{t}_{2}\left(60^{\circ} \mathrm{C}, 2 \mathrm{jam}\right)$ dengan rerata 4,47 (keharuman teh daun bambu tabah cukup khas), sedangkan aroma teh daun bambu tabah yang memiliki skor terendah adalah perlakuan $\mathrm{T}_{2} \mathrm{t}_{3}\left(60^{\circ} \mathrm{C}, 3 \mathrm{jam}\right)$ dengan rerata 4,13 (keharuman teh daun bambu tabah cukup khas). Hasil analisis sidik ragam teh daun bambu tabah menunjukan nilai $\mathrm{F}$ hitung lebih kecil dari nilai $\mathrm{F}$ tabel $5 \%$, menunjukkan tidak adanya pengaruh yang berbeda nyata terhadap warna teh daun bambu tabah. Hal ini diduga karena pendapat panelis terhadap aroma teh daun bambu tabah tidak terlau berbeda, sehingga rentan nilai yang diberikan tidak menunjukan perbedaan yang signifikan. Menurut Vesania, M. B. (2016) meskipun aroma dapat diketahui, namum setiap manusia mempunyai kesukaan yang berlainan, sehingga penilaian panelis dalam hal aroma rentan nilai pada setiap perlakuan tidak begitu berbeda. Menurut Anjarsari, B. (2015) aroma dalam bahan pangan dapat ditimbulkan oleh beberapa komponen volatil, akan tetapi komponen volatil tersebut dapat hilang selama proses pengolahan terlalu lama.

\section{Rasa air seduhan}

Hasil dari analisis sidik ragam menunjukkan bahwa interaksi pengaruh perlakuan suhu pengeringan dan lama waktu pengeringan tidak memberikan pengaruh yang bebeda nyata terhadap organoleptik rasa teh daun bambu tabah ( $\mathrm{P}>0,05)$. Hasil pengujian organoleptik terhadap aroma dapat dilihat pada Gambar 7.

\section{ค. T $50^{\circ} \mathrm{C}$}

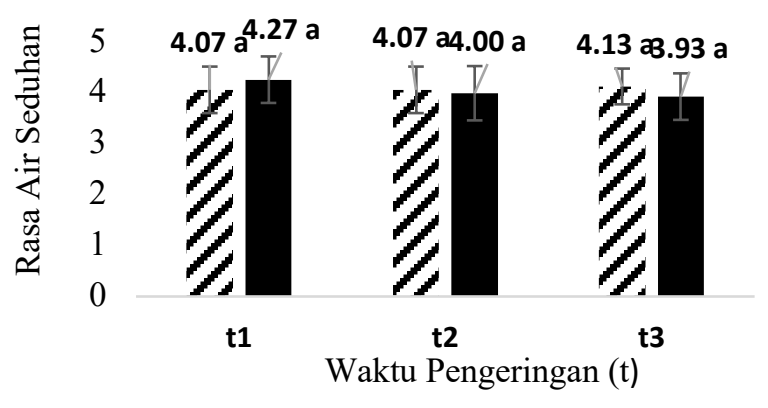

Gambar 7. Hubungan antara Suhu dan Waktu pengeringan terhadap rasa teh daun bambu tabah. Keterangan: 7. Interaksi dari perlakuan suhu dan waktu pengeringan menunjukkan tidak adanya interaksi $(\mathrm{P}>0,05)$

Berdasarkan hasil pengujian organoleptik, tingkat kesukaan panelis terhadap rasa teh daun bambu tabah yang memiliki skor tertinggi pada perlakuan $\mathrm{T}_{2} \mathrm{t}_{1}\left(60^{\circ}\right.$ C, 1 jam) dengan rerata 4,27 (rasa teh daun bambu cukup sepat), sedangkan rasa teh daun bambu tabah yang memiliki skor terendah adalah perlakuan $\mathrm{T}_{2} \mathrm{t}_{3}$ $\left(60^{\circ} \mathrm{C}, 3 \mathrm{jam}\right)$ dengan rerata 3,93 (rasa teh daun bambu cukup sepat).

Hasil analisis sidik ragam teh daun bambu tabah menunjukan nilai $\mathrm{F}$ hitung lebih kecil dari nilai $\mathrm{F}$ tabel 5\%, menunjukkan tidak adanya pengaruh yang berbeda nyata terhadap rasa teh daun bambu tabah. Hal ini disebabkan karena adanya senyawa fenol yang tinggi pada bahan. Semakin tinggi kandungan fenol yang terdapat pada teh daun bambu tabah akan menghasilkan rasa pahit atau sepat, sehingga kesukaan panelis akan menurun.

Menurut Harun, N. et al., (2014) rasa dipengaruhi oleh beberapa faktor yaitu senyawa kimia, suhu, konsentrasi dan interaksi dengan komponen rasa yang lain. Rusnayanti (2018) menyatakan senyawa yang berkontribusi untuk karakteristik rasa teh adalah senyawa polifenol (katekin), dan asam amino.

\section{Penerimaan Keseluruhan}

Hasil dari analisis sidik ragam menunjukkan bahwa interaksi suhu pengeringan dan waktu pengeringan berpengaruh nyata terhadap penerimaan keseluruhan pada teh daun bambu tabah $(\mathrm{P}<0,05)$. Adapun hasil 
penerimaan keseluruhan yang ditampilkan pada Gambar 8.

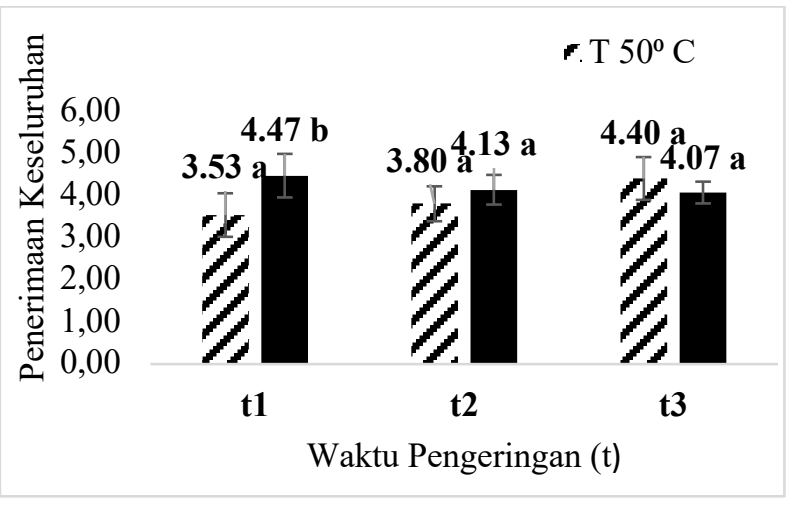

Gambar 8. Hubungan antara Suhu dan Waktu pengeringan terhadap penerimaan keseluruhan teh daun bambu tabah. Keterangan: 8. Huruf yang berbeda dibelakang angka pada kolom menunjukan adanya perbeda yang segnifikan berdasarkan uji BNT $(\mathrm{P}<0.05)$.

Berdasarkan hasil pengujian organoleptik, tingkat kesukaan panelis terhadap penerimaan keseluruhan teh daun bambu tabah yang memiliki skor tertinggi pada perlakuan $\mathrm{T}_{2} \mathrm{t}_{1}\left(60^{\circ} \mathrm{C}, 1 \mathrm{jam}\right)$ dengan rerata 4,47 (suka), sedangkan skor terendah terdapat pada perlakuan $\mathrm{T}_{1} \mathrm{t}_{1}\left(50^{\circ} \mathrm{C}, 1 \mathrm{jam}\right)$ dengan rerata 3,53 (netral).

Hasil analisis sidik ragam teh daun bambu tabah menunjukan nilai $\mathrm{F}$ hitung lebih besar dari nilai $\mathrm{F}$ tabel $5 \%$, menunjukkan adanya pengaruh nyata dari perlakuan suhu dan waktu pengeringan terhadap penerimaan keseluruhan teh daun bambu tabah. Selanjutnya perlu adanya perlakuan uji BNT 5\%. Hasil uji BNT $5 \%$ menunjukan bahwa perlakuan $\mathrm{T}_{1} \mathrm{t}_{1}$ $\left(50^{0} \mathrm{C}, 1 \mathrm{jam}\right), \mathrm{T}_{1} \mathrm{t}_{2}\left(50^{\circ} \mathrm{C}, 2 \mathrm{jam}\right), \mathrm{T}_{1} \mathrm{t}_{3}\left(50^{\circ} \mathrm{C}, 3 \mathrm{jam}\right)$, $\mathrm{T}_{2} \mathrm{t}_{2}\left(60^{\circ} \mathrm{C}, 2 \mathrm{jam}\right)$, dan $\mathrm{T}_{2} \mathrm{t}_{3}\left(60^{\circ} \mathrm{C}, 3 \mathrm{jam}\right)$ berbeda nyata dengan perlakuan $\mathrm{T}_{2} \mathrm{t}_{1}\left(60^{\circ} \mathrm{C}, 1 \mathrm{jam}\right)$. Hal ini diduga karena karakteristik sensori yang sangat mempengaruhi daya terima panelis terhadap teh daun bambu tabah adalah warna, aroma dan rasa seduhan teh, sehingga semakin sepat rasa seduhan teh daun bambu tabah dan warna seduhan kurang menerik kesukaan panelis cenderung akan menurun. Didukung oleh pernyataan Daroini (2016) bahwa penilaian keseluruhan dapat dikatakan gabungan dari warna, aroma dan rasa.

\section{KESIMPULAN DAN SARAN}

\section{Kesimpulan}

Berdasarkan hasil penelitian yang sudah dilakukan dapat disimpulkan bahwa suuhu dan waktu pengeringan pada proses pengolahan teh daun bambu tabah berpengaruh nyata terhadap kadar air, $\mathrm{pH}$, total asam, total fenol, warna (uji skorsing), penerimaan keseluruhan (uji Hedonik), namun tidak memberikan pengaruh nyata terhadap aroma (uji skorsing) dan rasa (uji skorsing). Perlakuan kombinasi terbaik terhadap kadar air, $\mathrm{pH}$, total asam, total fenol, warna teh daun bambu tabah terdapa pada suhu $60^{\circ} \mathrm{C}$ dan waktu pengeringan 3 jam dengan nilai : 6,881\%, 6,6, $0,73 \%, 84,01 \mathrm{mg} / 100 \mathrm{~g}$, dan warna dengan skor 4,33. Namun perlakuan terbaik pada rasa dan penerimaan keseluruhan teh daun bambu terdapat pada suhu $60^{\circ}$ $\mathrm{C}$ dan waktu pengeringan 1 jam dengan skor 4,27, dan 4,47. Sedangakan perlakuan terbaik pada aroma teh daun bambu tabah terdapat pada suhu $60^{\circ} \mathrm{C}$ dan waktu pengeringan 2 jam dengan skor 4,47 .

\section{Saran}

Berdasarkan hasil penelitian yang sudah dilakukan masih terdapat kekurangan dalam penelitian ini, maka penelitian selanjutnya disarankan untuk menggunakan

suhu dan waktu yang lebih lama agar mendapatkan hasil lebih baik. Serta perlu dilakukan kombinasi antara teh daun bambu tabah dengan bahan lain sehingga memberikan aroma dan rasa yang berbeda.

\section{DAFTAR PUSTAKA}

Andri, D., \& Hersoelistyoini, W. 2013. Aktivitas Antioksidan dan Sifat Organoleptik Teh Daun Sirsak (Annona Muricata Linn.) Berdasarkan Variasi Lama Pengeringan. Jurnal Pangan dan Gisi, 4(1).

Anjasari, B. 2015. Pengaruh Suhu dan Lama Pengeringan terhadap Karakteristik Teh Herbal Daun katuk (Sauropus adrogynus L. Merr). Doctoral dissertation. Fakultas Teknik Unpas.

AOAC. 1995. Official Methods of Analysis. Washington. Association of Official Analysis Chemists.

[BSN] Badan Standarisasi Nasional. 2016. SNI 3945: 2016. Syarat Mutu Teh Hijau. Jakarta: Badab Standarisasi Nasional. Hal 8.

Chu, D. C., \& Juneja, L.R. 1997. General chemical composition of green tea and its infusion. Chemistry and Applicatioans of Green Tea. 1322.

Daroini, O. S. 2006. Kajian proses pembuatan teh herbal dari campuran teh hijau (Camellia sinensis), rimpang bengle (Zingiber cassumunar Roxb), dan daun ceremai (Phyllanthus L. Skeels). Skripsi. Fakultas Pertanian IPB. Bogor.

Diantoro, A., Rohman, M., Budiarti, R., \& Palupi, H. T. 2015. Pengaruh penambahan ekstrak daun kelor (Moringa Oleifera L.) terhadap kualitas yoghurt. TEKNLOGI PANGAN: Media Informasi dan Komunikasi Ilmiah Teknologi Pertanian, 6(2). 
Gunawan, D. dan Mulyani, S. 2004. Ilmu Obat Alam. Penebar Swadaya : Jakarta.

Hambali, E., Nasution, M. Z., \& Herliana, E. 2005. Membuat Aneka Herbal Tea. Penebaran Swadaya. Jakarta.

Hartuti, N., \& Sinaga, R. M. 1997. Pengeringan cabai. Balai Penelitian Tanaman Sayuran. Pusat Penelitian dan Pengembangan Hortikultura Badan Penelitian dan Pengembangan Pertanian.

Javanmardi, J., Khalighi, A., Bais, H. P., \& Vivanio, J. M. 2003. Chemical Characterization of Basil (Ocimum Basiliam L.) Found in Local Accessions and Used in Traditional Medicines in Iran. Journal of Agriculture and Food Chemistry, 50. 5878-5883.

Kencana, P. K. D., Widia, W., and Antara, N. S. 2012. Praktek Baik Budidaya Bambu RebungTabah(Gigantochloa Nigrociliata Buse-Kurz), Pp. 1-69.

Manoi, F. 2015. Pengaruh Cara Pengeringan terhadap Mutu Simplisi Sambiloto. Buletin Penelitian Tanaman Rempah dan Obat. 17 (1). 1-5.

Morisco. 2006. Teknologi Bambu. Bahan Kuliah Magister Teknologi Bahan Bangunan. Program Studi Teknik Sipil Universitas Gajah Mada, Yogyakarta.

Ravikumar, C. 2014. Review On Herbal Teas. Journal Pharmaceutical Science \& Research 6(5): 236-238.

Rofiah, D. 2015. Aktivitas Antioksidan dan Sifat Organoleptik Teh Daun Kelor dengan Variasi Lama Pengeringan dan Penembahan Jahe serta Lengkuas sebagai Perasa Alami. (Doctoral dissertation). Universitas Muhamadiyah Surakarta.

Rusnayanti, Y. 2018. Pengaruh Suhu dan Lama Pengeringan terhadap Mutu Teh Hijau Daun Kakao (Theobroma cocoa L.). (Doctoral dissertation). Universitas Mataram.

Safriani, N., Novita, M., Sulaiman, I., \& Ratino, W. 2014. Pengemasan Manisan Kolang-Kaling Basah (Arenga pinnata L) dengan Bahan Kemas Plastik dan Botol Kaca Pada Penyimpanan Suhu Ruang. Rona Teknik Pertanian, 7(1), 3-44).

Sembiring, N. V. N. 2019. Pengaruh Kadar Air dari Bubuk Teh Hasil Fermentasi terhadap Kapasitas Produksi pada Stasiun Pengeringan di Pabrik Teh PTPN IV unit kebun Bah Butong. Karya Ilmiah. Universitas Sumatera, Mendan

Sudarmadji, S., Haryono, B., \& Suhardi. 1997. Prosedur Analisis untuk Bahan Makanan dan Pertanian. Liberty. Yogyakarta.

Sukandar, D. 2014. Aktivitas Antioksidan dan Mutu Sensori Formulasi Minuman Fungsional
Sawo-Kayu Manis. Jurnal Kimia Valensi, 4(2), 80-89.

Vesania, M. B. 2016. Pengaruh Penambahan Bubuk Daun Stevia Rebaudiana (Bertoni) terhadap Komposisi Fitokimia dan Aktivitas Antioksidan Minuman Teh Hitam.(Doctoral dissertation). Widya Mandala Catholic, Universitas Surabaya.

Widiarso, B. P., Nurcahyo, W., Prastowo, J., \& Kurniasih, K. 2019. Potensi Daun Bmabu Sebagai Agen Anthelmetika Pada Ternak Kambing (Bamboo Leaves Potency as Anthelmintic Agent on Goat). Jurnal Pengembangan Penyulihan Pertanian, 14(1), 134-143.

Winarno. F. G. 1997. Kimia Pangan dan Gizi. Jakarta: Gramedia Pustaka Utama.

Winarno, F.G. 2008. Kimia Pangan dan Gizi. 171172. M-Brio Press, Bogor. 